A N NALES

UNIVERSITATIS MARIAE CURIE-SKŁODOWSKA

LUBLIN - POLONIA

VOL. LXIX, 1

SECTIO C

2014

ADAM PAWEŁ KUBIAK ${ }^{1}$, RAFAŁ KRAWCZYK ${ }^{2}$

\author{
${ }^{1}$ Department of Geobotany, ${ }^{2}$ Department of Nature Conservation \\ Maria Curie-Skłodowska University, Akademicka 19, 20-033 Lublin, Poland \\ e-mail: adampkubiak@gmail.com, Rafal.Krawczyk@umcs.lublin.pl
}

\title{
Diversity of macrophytes in riverine aquatic habitats: comparing active river channel and its cut-offs
}

\author{
Różnorodność makrofitów w nadrzecznych siedliskach wodnych: porównanie \\ koryta rzeki ze starorzeczami
}

\begin{abstract}
SUMMARY
The study area was a small lowland river valley (the Łęg river) located in the south-east of Poland. The object of investigation was the macrophytes of 10 river lakes with corresponding active river channel stretches of the same length as the cut-offs. The aim was to check the difference in species diversity between cut-off and active river channels. The second aim was to test the following hypothesis: vegetation of river lake has been shaped under the influence of contiguous river stretch which has left a measurable mark in species abundance and composition. To test this, we checked whether a cut-off channel's flora is more similar to flora of the contiguous river stretch, than to flora of a farther river stretch. During the course of the study it was found that the average species richness was approximately two times higher in the cut-off channels than in the river stretches. The number of the species exclusive for the river lakes was nine times higher in comparison with the river's exclusives (not found in the cut-offs). The Shannon diversity index definitely spoke in favor of the river lakes. These results clearly show the significance of river lakes in maintaining biodiversity of aquatic ecosystems in a small river valley. We did not confirm our hypothesis concerning floristic relation between an active channel and its cut-offs. The floristic similarity between a given cut-off channel and the contiguous active river channel stretch is not stronger than the similarity between this lake and more distant river stretches. The cause of such a state of affairs may be high natural dynamics of investigated habitats and anthropogenic transformation of the river valley.
\end{abstract}

Key words: macrophytes, species diversity, river lakes, cut-offs, river channel, SE Poland 


\section{STRESZCZENIE}

Badania dotyczyły różnorodności flory wodnej i szuwarowej porastającej starorzecza i aktualne koryto niewielkiej rzeki nizinnej Łęg, przepływającej przez centralną część Kotliny Sandomierskiej. Wytypowano 10 par starorzecze-rzeka; danemu starorzeczu odpowiadał najbliżej położony względem niego fragment rzeki o tej samej długości co starorzecze. Pierwszym celem było porównanie różnorodności gatunkowej flory aktywnego i odciętego koryta rzeki. Drugim zadaniem badawczym było przetestowanie następującej hipotezy: roślinność starorzecza kształtuje się pod wpływem przyległego odcinka rzeki, co pozostawia mierzalny ślad w kompozycji gatunków oraz ich ilościowych stosunkach. W tym celu sprawdzono czy podobieństwo florystyczne pomiędzy określonym starorzeczem a najbliższym mu fragmentem rzeki jest istotnie większe niż pomiędzy tym starorzeczem a bardziej odległymi fragmentami aktywnego koryta rzeki. W wyniku przeprowadzonych badań stwierdzono, że średnie bogactwo gatunkowe w starorzeczach było prawie dwa razy większe niż na odcinku rzeki o tej samej długości. Liczba gatunków stwierdzonych wyłącznie w starorzeczach była dziewięć razy większa od liczby gatunków rzeki stwierdzonych tylko w rzece. Wartość wskaźnika różnorodności Shannona-Wienera była istotnie wyższa dla starorzeczy. Wyniki te wyraźnie wskazują na znaczenie jezior rzecznych w zachowaniu różnorodności biologicznej ekosystemów wodnych w dolinie małej rzeki nizinnej. Hipoteza dotycząca florystycznych powiązań pomiędzy sąsiadującymi ze sobą dwoma typami ekosystemów nie została potwierdzona. Podobieństwa pomiędzy starorzeczem i najbliższym mu odcinkiem rzeki nie było większe niż podobieństwo pomiędzy tym starorzeczem a oddalonym odcinkiem rzeki. Taki stan rzeczy może mieć swoje źródło zarówno w naturalnych procesach (duża dynamika badanych ekosystemów) jak i w antropogenicznych przekształceniach doliny.

Słowa kluczowe: makrofity, różnorodność gatunkowa, starorzecza, koryto rzeki, SE Polska

\section{INTRODUCTION}

A river channel and its cut-off parts (river lakes) form a complex and dynamic system which depends on geomorphological and ecological processes, such as erosion, succession and connectivity $(1,3,7,14)$. In a river valley, river lakes substantially contribute to the growth of species diversity. However, because of human activity which started at the end of the Holocene, river lakes are nowadays highly threatened ecosystems. Vegetation development in a river channel depends above all on the channel's morphology and hydraulic parameters $(5,10)$. Small rivers are usually inhabited by aquatic and rush species. Superficial observations indicate that species richness of river lake ecosystem is higher than species richness of an active channel, even in the most natural ecosystems - this is due to more stable ecological conditions.

After establishing a new river lake, this ecosystem changes its character from lotic to lentic and it redirects succession of vegetation. The first inhabitants of the new ecosystem are organisms which previously lived in the channel, and other species migrate from local populations. Newcomers interact with the present inhabitants and change the structure of vegetation, which results in a new equilibrium. As the lake-originative stretch of the river channel is a starting point of a succession for the new ecosystem, it should determine, to some extent, the structure of subsequent communities of the river lake. Additionally, short distance between the river lake and the contiguous river stretch make the propagules exchange easy. The influence of the nearest river stretch upon species composition of cut-off channel is strong in the initial stage of succession and gradually decreases over time. Nevertheless, it can be assumed that the mark of common history of vegetation development is measurable at present with the use of similarity indices. Even if the vegetation along the river 
channel is significantly homogeneous, similarity between a given river lake and the nearest stretch of river should be higher than more distant one.

The studies dealing with macrophytes in river lakes were extensively conducted during the last two decades, in particular on the topic of long- and short-term changes of vegetation and species abundance against lake's morphology, connectivity, water-level fluctuations and abiotic water conditions $(1,2,3,7,14,25,26)$. Various studies on river lake's vegetation were also carried out in Poland $(9,13,15,16,18,20,23)$. Nevertheless, the literature lacks of qualitative or quantitative comparison of plant diversity between cut-off channels and its parent river. We carried out the research in the valley of a small lowland river situated in the south-west of Poland. Our first aim was to check the difference in species diversity between cut-off and active river channel. The second aim was to test the following hypothesis: vegetation of river lake has been shaped under the influence of vegetation of contiguous river stretch which has left a measurable mark in floristic composition.

\section{STUDY AREA}

The Łęg river is a lowland stream which runs through the central part of Sandomierz Basin (12). It flows from the Kolbuszowa Plateau, through the Tarnobrzeg Plain, and gets to the Vistula river near the city of Sandomierz. The length of its course is $82 \mathrm{~km}$, drainage basin covers $960 \mathrm{~km}^{2}$. The channel width is about $15 \mathrm{~m}$, in some places small islands are formed. In the investigated section of the valley, the Łęg river runs through a plain covered with fine-grained sands of various origin (28). The climate of the investigated area is moderately humid and one of the hottest in Poland (11).

The Łęg river valley cuts across the Sandomierz Forest. Until 1456, the region had the status of an exclusive hunting district of the Jagiellonian royal family (11). In the $18^{\text {th }}$ century, after the introduction of more arranged/extensive farming, the landscape of the Łęg river valley took on an agricultural character - nowadays a significant part of the lowest terrace is occupied by agricultural wastelands.

River regulation and storage reservoir construction in Wilcza Wola (upstream of the investigated area) have altered natural flow regime and significantly reduced connectivity between the river and its cut-offs. At present, the river has a low sinuosity, and the process of forming new lakes is not observed. In the northern part (beginning from Grębów), Lęg's channel is highly humantransformed: straightened and narrowly embanked.

\section{MATERIAL AND METHODS}

Field research was conducted in summer 2009 and 2010. Ten river lakes situated between Bojanów and Gorzyce were investigated. The lakes which were taken into account were not entirely overgrown with non-aquatic vegetation and not largely anthropogenic-transformed. The same number of stretches of the river's channel, equal in their length to the river lake and adjacent (the nearest) to the river lakes, were investigated; ten pairs for testing were obtained. River lakes characteristics (length, geographical coordinates and the nearest distance to river) were given in Appendix I. In the case of the river lakes, observations were carried out in the whole area of water body: plants were picked out from shallow water by hand; a grapnel was used for plants growing in deep water away from banks. In the case of the river, plants were noted down during wading in the river bed along the whole length of a given fragment. Aquatic and rush species which were taken into account are characteristic for phytosociological classes Charetea, Lemnetea, Potametea and Phragmitetea (17). Species abundance with regard to the whole surface of the water body was estimated with the use of Braun-Blanquet (4) scale: $\mathrm{r},+, 1,2,3,4,5$. 
For the sake of specification of degree to which cut-off channel differs from active river channel in terms of species diversity, the following indices were calculated for each of the twenty objects: /1/ species richness (number of macrophytes) S, /2/ Shannon-Wiener's index H (21) and $/ 3 /$ evenness index E (19). For the purpose of computing, Braun-Blanquet scale values were transformed into midpoints of intervals presented by the scale ("+" was transformed into 0.5 , " $r$ " into 0.1 ). The significance of the difference between indices values was checked by Wilcoxon paired test. Moreover, numbers of species exclusive for both types of ecosystems were determined.

The hypothesis concerning floristic relation between river lake and contiguous river stretch (the mark of shared history of vegetation development) was tested by comparing values of floristic similarity indices. Jaccard and Ružicka indices (8) were computed for two pairs: /1/ river lake the nearest river stretch and $/ 2 /$ river lake - randomly chosen river channel stretch. To calculate Ružicka index, Braun-Blanquet's scale was transformed into 9-point ordinal scale according to van der Maarel (24). The relevance of differences was calculated by Wilcoxon paired test. Statistical analyses were carried out using STATISTICA StatSoft package. The distance between lake and river stretch were determined using binomial scale (nearest, farther) which is independent of real distances to river of particular lakes. We also assumed that river lakes are of similar age (we took into account that new lakes with pioneer vegetation were not observed and lifespan of shallow lakes in agricultural landscape is relatively short).

\section{RESULTS}

In total, 56 aquatic and rush macrophytes were found in 20 surveyed objects (Tab. 1). In cut-off channels the species richness was approximately twice as high as (1.89) in the active river channel stretches (Wilcoxon test: $\mathrm{T}=0, \mathrm{p}<0.01$; Fig. 1a). Also species diversity, expressed as the value of Shannon-Wiener's index, for river lakes was 1.8 times higher than in the case of river (Wilcoxon test: $\mathrm{T}=0, \mathrm{p}<0.01$; Fig. 1b). The comparison of values of evenness index showed that the cause of higher biodiversity of river lakes (when compared with biodiversity of the river channel) was mainly a higher number of species; qualitative species' cover relations were less relevant: for the $E$ index differences were not statistically significant (Wilcoxon test: $\mathrm{T}=10$, n.s.; Fig. 1c). Moreover, almost half (45\%) of all found species were present only in river lakes, whereas merely $5 \%$ of all species were exclusive for the river. Majority of aquatic species occurred only in river lakes; species common for the river and cut-offs are mostly helophytes (Tab. 1).

Differences between average values of Jaccard index for pairs river lake-the nearest river stretch and river lake-random river channel stretch, were insignificant (Wilcoxon test: $T=26$, n.s.). Similar result was obtained using Ružicka index (Wilcoxon test: $\mathrm{T}=18$, n.s.).

\section{DISCUSSION}

In complex riverine landscape, aquatic habitats are structured by many biotic and abiotic factors. Nutrient content, morphometric characteristics, age, water level fluctuation, hydrological connectivity and flood disturbance are frequently 
pointed out to be the essential drivers shaping macrophytes diversity of cut-off channels $(1,2,3,13,15,25,26,27)$. Our main findings confirm an intuitive thesis that species diversity of river lake ecosystems significantly exceeds species richness of an active river channel. Aquatic and rush plant communities develop intensely in river lakes and slightly in a river (9). The flow of the water - its velocity and discharge regime - seems to have a decisive effect on the occurrence of differences in plant species diversity between a river channel and its isolated fragments. Destructive water scouring causes the reduction of plants and prevents the development of more diversified and species-rich vegetation. Only the species resistant to perturbation, such as Phalaris arundinacea, Glyceria fluitans, Glyceria maxima occur regularly, whilst species of stable habitat, e.g., Hydrocharis morsus-ranae, Carex pseudocyperus, Riccia fluitans, Nuphar lutea, Stratiotes aloides, Typha latifolia or Utricularia vulgaris can show up only occasionally. In the view of intermediate disturbance hypothesis (6), a river can be treated as an extreme case of water ecosystem which is subjected to permanent disturbance limiting species diversity. Our outcome supports the presented theory and specifies it for the case of a small, temperate, lowland river.

The research did not confirm the mechanism drafted in the introductory section which concerned the development of river lake's phytocoenoses: there was no significant difference between river lake's floristic similarity to the nearest river fragment and its similarity to a (randomly chosen) distant river fragment. It may indicate, firstly, that we did not reveal the mark of common history of vegetation development - which means that historical influence lost its significance, the nearest river species composition underwent significant change, or both; and secondly, that the nearest river stretch is not privileged among other stretches in possible influence on the character of adjacent cut-off lake's flora at present. A possible natural cause for such an outcome may be low stability of riverine and water habitats, and homogenization caused by longitudinal river connectivity (22). Another cause can be anthropogenic transformations (e.g., river regulation) altering natural processes $(5,14)$. Predictions arising from our hypothesis should give better results in more natural valleys with large number of river lakes of young generation.

The results of our research serve as a strong argument for protection of river lakes: they should be regarded as essential for maintaining plant biodiversity in water ecosystems of river valley. If the cut-off channels and artificial reservoirs in investigated river valley were to disappear due to human impact, then the number of water and rush species may decrease by half, including the loss of many rare species. 


\section{REFERENCES}

1. Bornette G., Amoros C., Lamouroux N. 1998. Aquatic plant diversity in riverine wetlands: the role of connectivity. Freshwater Biology 39(2): 267-283.

2. Bornette G., Amoros C., Piegay H., Tachet J., Hein T. 1998. Ecological complexity of wetlands within a river landscape. Biological Conservation 85: 35-45.

3. Bornette G., Piegay H., Citterio A., Amoros C., Godreau V. 2001. Aquatic plant diversity in four river floodplains: a comparison at two hierarchical levels. Biodiversity and Conservation 10: 1683-1701.

4. Braun-Blanquet J. 1964. Pflanzensoziologie, Grundzüge der Vegetationskunde (3-rd edition). Springer Verlag, Vienna.

5. Bunn S.E., Arthington A.H. 2002. Basic principles and ecological consequences of altered flow regimes for aquatic biodiversity. Environmental Management 30(4): 492-507.

6. Connell J. H. 1978. Diversity in tropical rain forests and coral reefs. Science 199: 1302-1310.

7. Cristofor S., Vadineanu A., Sarbu A., Postolache C., Dobre R., Adamescu M. 2003. Long-term changes of submerged macrophytes in the Lower Danube Wetland System. Hydrobiologia 506509: 625-634.

8. Dzwonko Z. 2008. Przewodnik do badań fitosocjologicznych. Vademecum Geobotanicum. Sorus, Poznań-Kraków.

9. Fijałkowski D. 1966. Zbiorowiska roślinne lewobrzeżnej doliny Bugu w granicach województwa Lubelskiego. Annales Univ. M. Curie-Skłodowska, sec. C, 21: 247-312.

10. Franklin P., Dunbar M., Whitehead P. 2008. Flow controls on lowland river macrophytes: A review. Science of the Total Environment 400: 369-378.

11. Głowaciński Z., Michalik S. 1979. Kotlina Sandomierska. Wiedza Powszechna, Warszawa.

12. Kondracki J. 2002. Geografia regionalna Polski. PWN, Warszawa.

13. Krawczyk R. 2010. Species richness and vegetation structure in different morphogenetic types of river lakes in the San River valley. Annales Univ. M. Curie-Skłodowska, sec. C, 65(1): $29-45$.

14. Leyer I. 2005. Predicting plant species' responses to river regulation: the role of water level fluctuations. Journal of Applied Ecology 42: 239-250.

15. Lorens B. 2006. Szata roślinna jezior rzecznych oraz ich różnorodność fitocenotyczna i gatunkowa. [In:] W. Wojciechowska (ed.). Jeziora rzeczne doliny środkowego Bugu. Różnorodność biologiczna i krajobrazowa. Wyd. KUL.

16. Macicka-Pawlik T., Wilczyńska W. 1996. Zbiorowiska roślinne starorzeczy w dolinie środkowego biegu Odry. Acta Univ. Wratisl. 64: 73-120.

17. Matuszkiewicz W. 2008. Przewodnik do oznaczania zbiorowisk roślinnych Polski. PWN, Warszawa.

18. Michalska-Hejduk D., Kopeć D., Drobniewska A., Sumorok B. 2009. Comparison of physical and chemical properties of water and floristic diversity of oxbow lakes under different levels of human pressure: A case study of the lower San River (Poland). Ecohydrology and Hydrobiology 9(2-4): 183-191.

19. Pielou E.C. 1969. An introduction to mathematical ecology. Wiley, New York.

20. Ratyńska H., Szwed W. 1999. Struktura roślinności starorzeczy jako wyraz dynamiki warunków siedliskowych. Przegląd Przyrodniczy 10(3-4): 33-48.

21. Shannon C.E., Weaver W. 1949. The mathematical theory of communication. University of Illinois Press, Urbana.

22. Thomaz S.M., Bini L.M., Bozelli R.L. 2007. Floods increase similarity among aquatic habitats in river-floodplain systems. Hydrobiologia 579: 1-13. 
23. Urban D., Wójciak H. 2004. Water and rush plant associations of the Bug Valley old river-bed (Kryłów - Kodeń section) vis-à-vis the habitat conditions. Teka Komisji Ochrony i Kształtowania Środowiska Przyrodniczego 1: 293-300.

24. van der Maarel E. 1979. Transformation of cover-abundance values in phytosociology and its effects on community similarity. Vegetatio 39: 97-114.

25. Van Geest G.J., Coops H., Roijackers R.M.M., Buijse A.D., Scheffer M. 2005. Succession of aquatic vegetation driven by reduced water-level fluctuations in floodplain lakes. Journal of Applied Ecology 42: 251-260.

26. Van Geest G.J., Roozen F.C.J.M., Coops H., Roijackers R. M. M., Buijse A. D., Peeters E.T.H.M. Scheffer M. 2003. Vegetation abundance in lowland flood plain lakes determined by surface area, age and connectivity. Freshwater Biology 48(3): 440-454.

27. Ward J. V., Tockner K, Schiemer F. 1999. Biodiversity of floodplain river ecosystems: Ecotones and connectivity. Regulated Rivers 15: 125-139.

28. Wojtanowicz J. 1990. Podział fizycznogeograficzny Kotliny Sandomierskiej. Annales Univ. M. Curie-Skłodowska, Sect. B, 44/45: 67-93.

\section{Appendix I}

Characteristics of the investigated river lakes. Following the number of a river lake, the name of locality, geographical coordinates of the object midpoint, the length $[\mathrm{m}](\mathrm{l})$ and minimal distance to the river $[\mathrm{m}](\mathrm{d})$ were given.

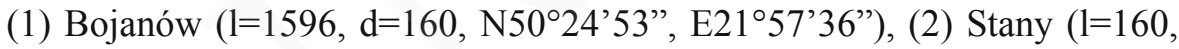
d=330, N50²6'8', E2159'27'), (3) Kołodzieje (l=405 d=100, N50²7'24’, E220'21"), (4) Przyszów-Występ (l=150, d=250, N50²8'44”, E22¹'03”), (5) Przyszów-Kliny (l=400, d=145, N50²8'53”, E220’47”), (6) Przyszów (l=789, $\left.\mathrm{d}=397, \mathrm{~N} 50^{\circ} 29^{\prime} 22^{\prime \prime}, \mathrm{E} 21^{\circ} 59^{\prime} 32^{\prime \prime}\right)$, (7) Krawce-Zimna Smuga $(\mathrm{l}=175, \mathrm{~d}=45$,

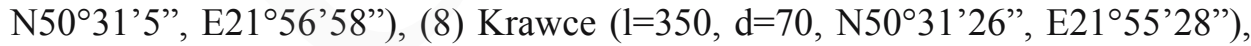
(9) Nowy Grębów ( $\left.1=423, d=222, \mathrm{~N} 50^{\circ} 33^{\prime 2} 21^{\prime \prime}, \mathrm{E} 21^{\circ} 54^{\prime} 23^{\prime \prime}\right)$, (10) Kępie Zaleszańskie (l=765, d=75, N50³8'34”, E2151'28'). 
Pobrane z czasopisma Annales C - Biologia http://biologia.annales.umcs.pl

Data: 26/04/2023 12:58:58

56

ADAM PAWEŁ KUBIAK, RAFAŁ KRAWCZYK

Tab. 1. Abundance of macrophytes specified in Braun-Blanquet scale in river lakes and river channel stretches. The species were arranged according to their similarity of occurrence in two types of investigated habitats.

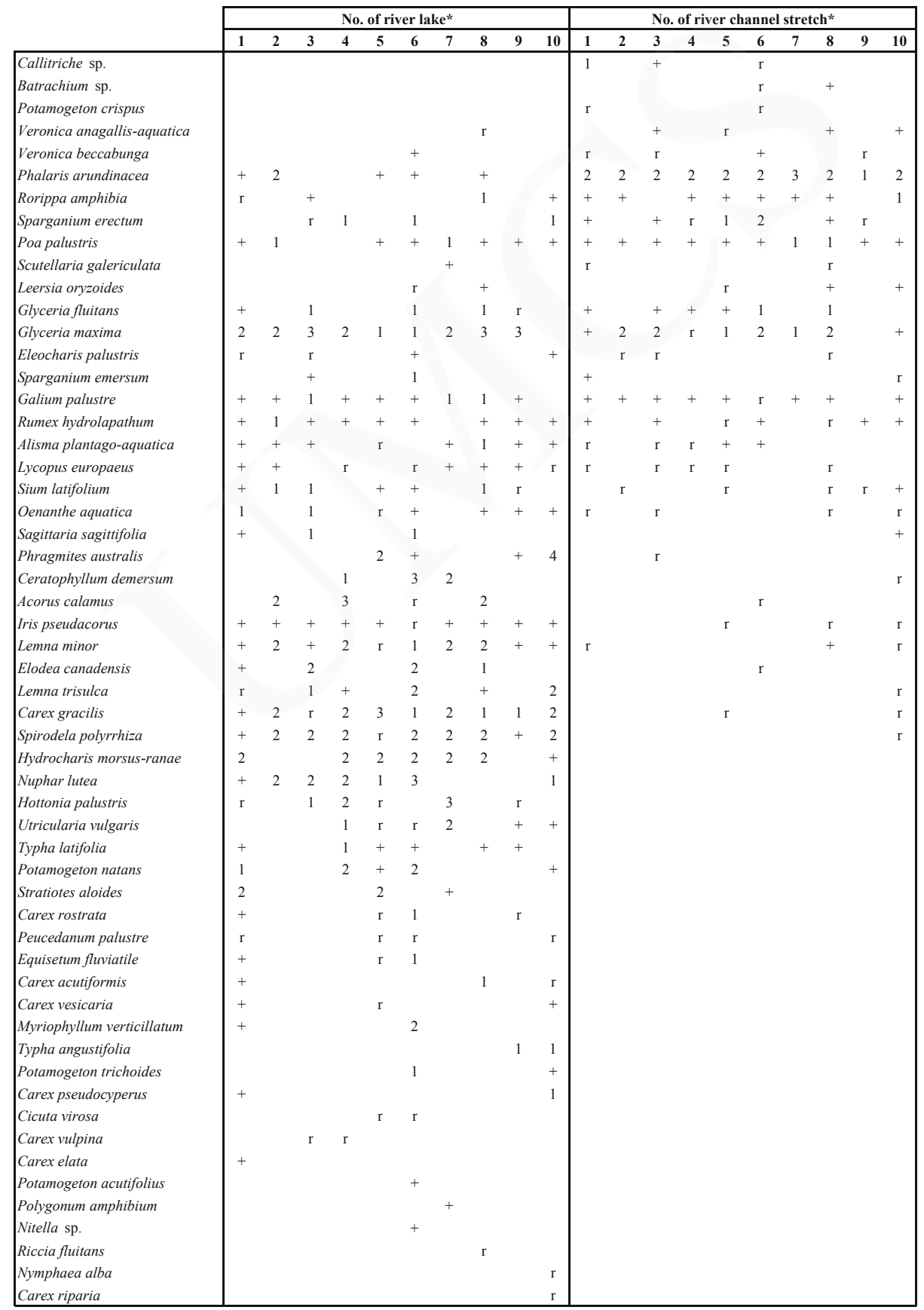


Pobrane z czasopisma Annales C - Biologia http://biologia.annales.umcs.pl

Data: 26/04/2023 12:58:58
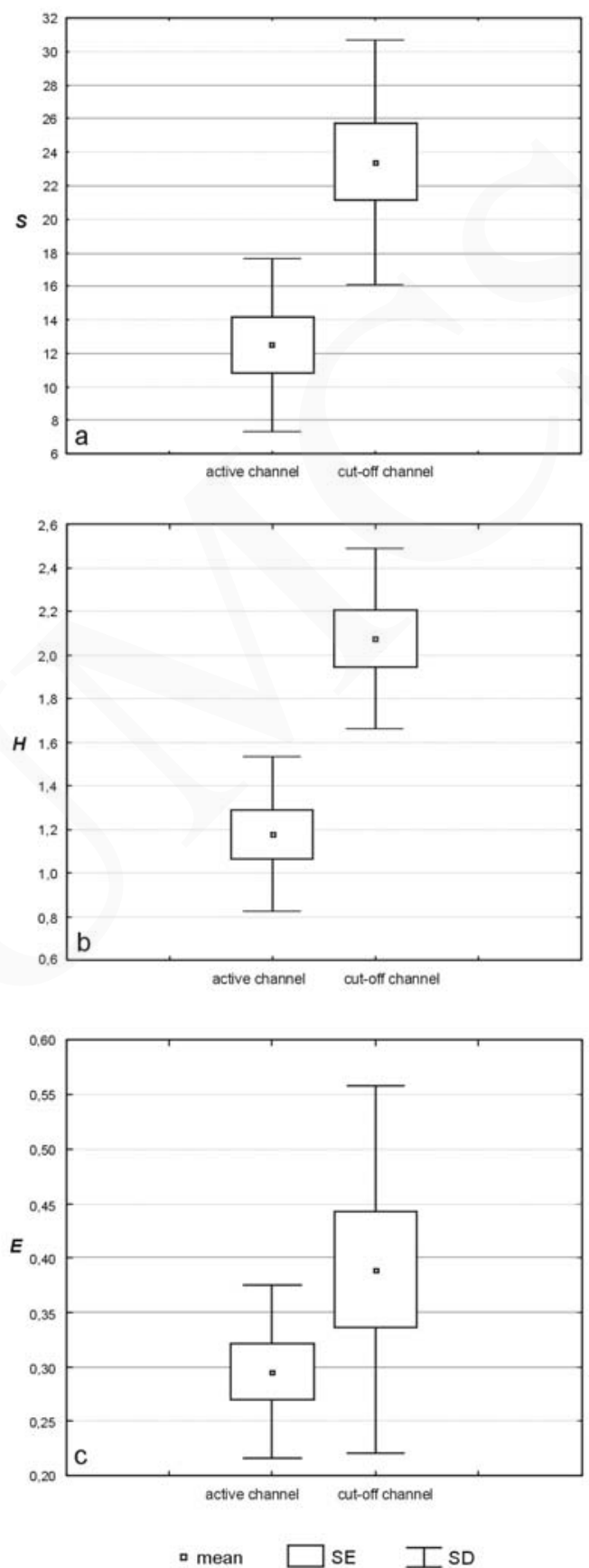

Fig. 1. Comparison of diversity of macrophytes in active river channel stretches and cut-off river channels: $\mathrm{a}$ - species richness, $\mathrm{b}$-Shannon-Wiener index, $\mathrm{c}-$ evenness index. 